Sharif University of Technology
Scientia Iranica
SCIENTIA
I RAN I C A
http://scientiairanica.sharif.edu

\title{
Systematic approach to the design of modular military housing units using six-sigma
}

\author{
B.-H. Cho ${ }^{\mathrm{a}}$, D.-J. Kim ${ }^{\mathrm{b}, *}$, and T. $\mathrm{Ha}^{\mathrm{c}}$ \\ a. Department of Architectural Engineering, Ajou University, 206 Worldcup-ro, Yeongtong-gu, Suwon-si, Gyeonggi-do 16499, South \\ Korea. \\ b. Department of Architectural Engineering, Kyung Hee University, 1732, Deogyeong-daero, Giheung-gu, Yongin-si, Gyeonggi-do \\ 17104, South Korea. \\ c. Steel Solution Center, POSCO, 100 Songdogwahak-ro, Yeonsu-gu, Incheon 21985, South Korea.
}

Received 16 October 2016; accepted 27 January 2018

\section{KEYWORDS}

Six-Sigma;

Modular construction;

Quality function

deployment;

Military housing unit;

Steel structure.

\begin{abstract}
Military quarters and barracks are representative of housing units where the same plan is repeated and, thus, prefabricated housing production can be effectively applied. These housing units are required to be disassembled and recycled as military forces are frequently reorganized and deployed to perform military actions. In order to meet these needs, this study proposes a systematic approach to the design of modular military housing units based on Six-Sigma concept. The application of Six-Sigma to modular military housing units allows customers' needs to be reflected on the critical-to-quality parameter, which summarizes the main design requirements. In addition, the design concept of the modular units can be developed based on the derived critical-to-quality functionalities. To evaluate the effectiveness of the proposed approach, a representative example of military housing units is chosen and designed by utilizing the new modular units developed through this procedure. The weight of frames per unit area and factory manufacturing ratio of the new design are analyzed. The results of the comparison show that the use of the new modular units not only reduces construction cost significantly, but also greatly improves the quality of construction.
\end{abstract}

(C) 2019 Sharif University of Technology. All rights reserved.

\section{Introduction}

Modular construction can be defined as a threedimensional volumetric unit that can be manufactured in a factory, delivered to the construction site, and assembled as the main structural elements of the building [1]. It has been widely applied to many different types of building construction in Europe and

\footnotetext{
*. Corresponding author. Tel.: 82312013329 Fax: 82 312028854

E-mail addresses: bhcho@ajou.ac.kr (B.-H. Cho); djkim@khu.ac.kr (D.-J. Kim); hath@posco.com (T. Ha)
}

doi: $10.24200 /$ sci. 2018.20162
Japan. In Korea, it has been applied mainly to school buildings and military facilities [2].

Military barracks and Bachelor Officers' Quarters (BOQs) are representative housing units that use the same plan repeatedly, which makes them good candidates for prefabricated housing production. These housing units must be disassembled and recycled because military forces are frequently reorganized and deployed to various locations. In Korea, the military owns 100,000 buildings nationwide in a total area of 25.2 million $\mathrm{m}^{2}$; however, approximately $30 \%$ of the building facilities are more than 20 years old. Therefore, new construction methods are required to improve the quality of military facilities. For this purpose, modular construction has been applied in Korea to 


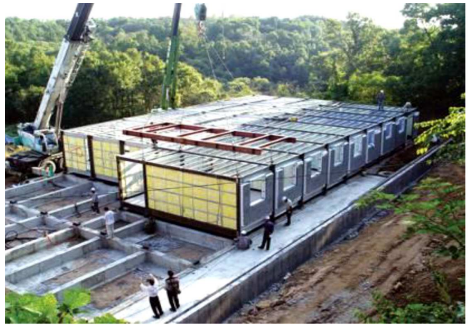

(a) Platoon military barrack

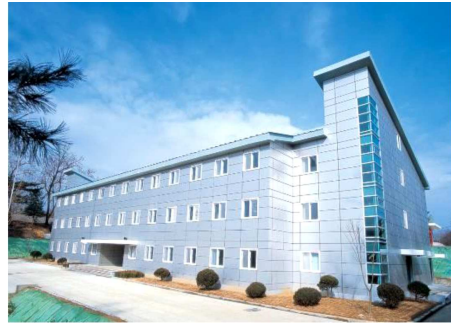

(b) Battalion barrack

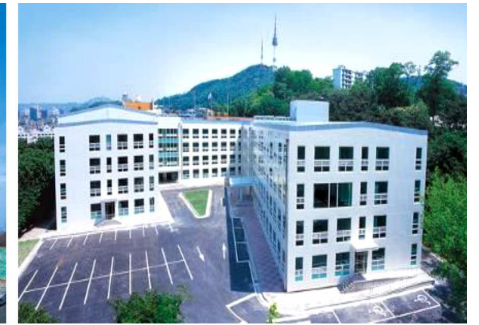

(c) Military office

Figure 1. Modular military facilities in Korea.

the construction of platoon barracks, military offices, battalion barracks, and BOQs, as shown in Figure 1. In the process of applying modular construction to military facilities, the important factors include cost reduction through the standardization of construction units and reusability of the construction elements that are disassembled at the end of their useful life. Most existing military modular construction facilities in Korea fail to meet those requirements [3].

In order to address this issue, this study develops new military housing units based on the so-called Six-Sigma methodology [4]. The Six-Sigma was first developed by Motorola in the 1980s [5] and became well-known in the 1990s when Jack Welch applied it to develop strategies for his company, General Electric. The application of the Six-Sigma to modular military housing units allows customers' needs to be reflected on the critical to quality, which summarizes the main design requirements. The design concept of the modular units can be developed based on the Critical To Qualities (CTQs). To evaluate the effectiveness of the proposed approach, a representative example of military quarters is chosen and designed by utilizing both the new modular units developed through this procedure and existing modular units. The frame mass per unit area and prefabrication ratio of the two cases are compared and analyzed.

\section{Derivation of CTQ for modular military housing}

In order to derive the requirements for modular military housing units, potential customers are grouped into one of the two following categories: external and internal customers. The former consists of design firms, module manufacturers, and contractors; the latter includes owners and residents. The requirements of the two customer groups for the modular military housing are listed in Table 1, which summarizes the results of customer interviews. In the table, "raw data", which are also called the voice of customers, represent the customers' opinions on existing military modular units, and "required quality" represents the quality of the product required to reflect the customers'

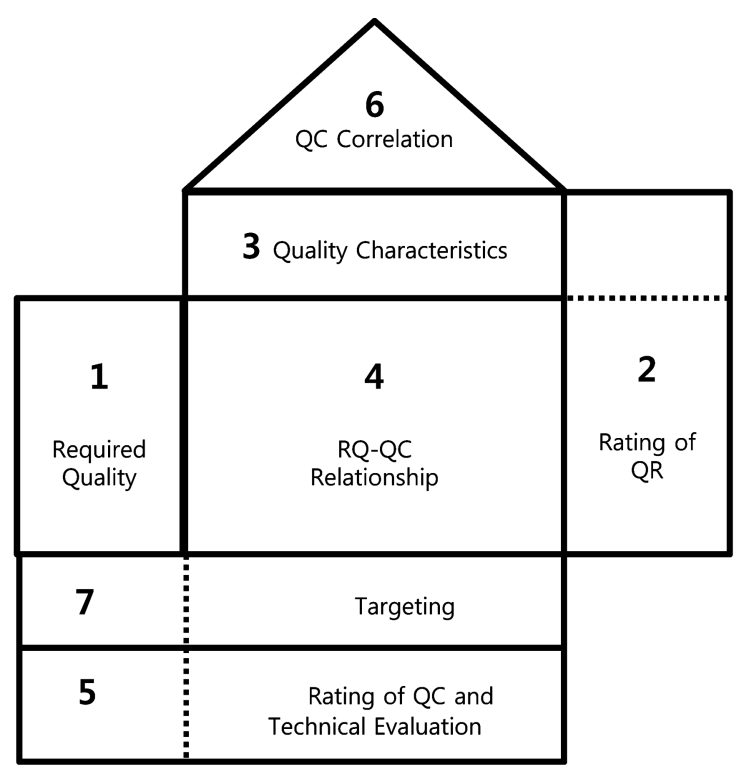

Figure 2. House of quality for quality function deployment analysis.

opinions. The required quality derived from the Voice Of Customer (VOC) in the interviews can be converted to quality characteristics for design through the House Of Quality (HOQ) structure, as illustrated in Figure 2. The HOQ organizes items based on the required qualities given in Table 1 . The importance and satisfaction of each item are assessed through a survey of customers.

Figure 3 shows the importance and satisfaction evaluation of the customers' requirements. The items of "short construction period", "easy to disassemble", "compatible to other modules", and "low construction cost" are considered to be highly important; however, the evaluation of the performance of the existing system regarding these items receives low ratings. Based on these results, Table 2 provides the priority rating on the customers' required qualities. Based on the results of the table, items with high priority are found to include "easy to disassemble", "reduction of construction cost", and "shortening of construction time period."

This study uses the Quality Function Deployment 
Table 1. Requirements of potential customer groups.

\begin{tabular}{|c|c|c|c|}
\hline \multirow[t]{2}{*}{ Customers } & $\begin{array}{l}\text { Voice of } \\
\text { customer }\end{array}$ & Scene & \multirow[t]{2}{*}{ Required quality } \\
\hline & & Who, where, when & \\
\hline Architect & Poor exterior design & $\begin{array}{l}\text { Architects design modular } \\
\text { buildings using the } \\
\text { developed modules }\end{array}$ & $\begin{array}{l}\text { Introduction of various } \\
\text { exterior designs }\end{array}$ \\
\hline \multirow{2}{*}{$\begin{array}{l}\text { Module } \\
\text { manufacturer }\end{array}$} & $\begin{array}{l}\text { Using too many } \\
\text { kinds of materials }\end{array}$ & $\begin{array}{l}\text { Manufacturers reserve } \\
\text { key materials for modules } \\
\text { in stock at the factory }\end{array}$ & Using standard materials \\
\hline & $\begin{array}{l}\text { Difficult to deliver modules. } \\
\text { High cost for delivery }\end{array}$ & $\begin{array}{l}\text { Manufacturers deliver } \\
\text { modules to the } \\
\text { construction site }\end{array}$ & Easy delivery of modules \\
\hline Contractor & $\begin{array}{l}\text { Damage occurring during } \\
\text { delivery and installation } \\
\text { of modules }\end{array}$ & $\begin{array}{l}\text { Contractors install modules } \\
\text { at construction site }\end{array}$ & $\begin{array}{l}\text { Safe for rainfall and } \\
\text { minimized damages during } \\
\text { delivery }\end{array}$ \\
\hline \multirow{2}{*}{ Owner } & $\begin{array}{l}\text { Higher construction } \\
\text { cost than that of } \\
\text { conventional methods }\end{array}$ & $\begin{array}{l}\text { The owner compares } \\
\text { the costs of traditional } \\
\text { and modular } \\
\text { construction methods }\end{array}$ & Low construction cost \\
\hline & Not easy to reuse & $\begin{array}{l}\text { The owner disassembles } \\
\text { modules to deploy military } \\
\text { forces after using } \\
\text { them many years }\end{array}$ & $\begin{array}{l}\text { Easy to disassemble } \\
\text { and deliver }\end{array}$ \\
\hline User & $\begin{array}{l}\text { Poor residential performance } \\
\text { of existing modular buildings }\end{array}$ & $\begin{array}{l}\text { Residents stay in the } \\
\text { housing after work }\end{array}$ & $\begin{array}{l}\text { Excellent thermal, optical, } \\
\text { and sound performances }\end{array}$ \\
\hline
\end{tabular}

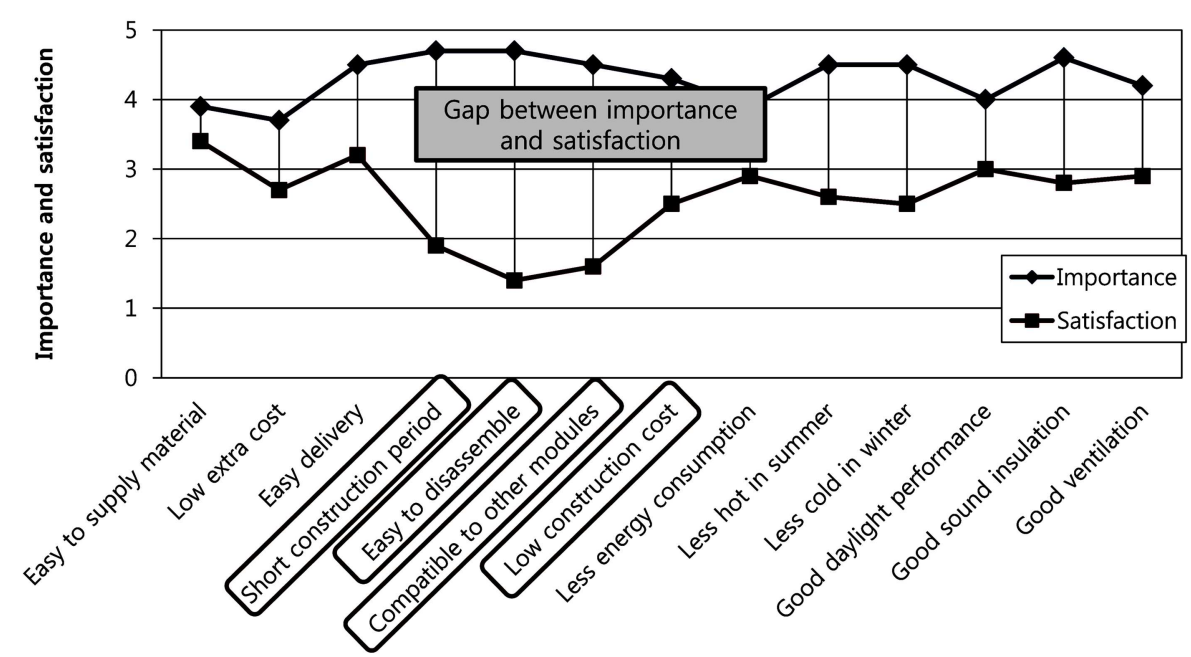

Figure 3. Importance and satisfaction evaluation of the customer's requirements.

(QFD) methodology to convert customers' required qualities into the quality characteristics of the products to be developed. The QFD methodology is a tool that can make a quantitative evaluation of the relation between the customer required qualities and product characteristics using a correlation matrix [6]. The results of the analysis using the correlation matrix are provided in Table 3. Based on the correlation analysis, parameters that are critical to quality from the customers' perspective can be 
Table 2. Priority rating of the customers' required qualities.

\begin{tabular}{|c|c|c|c|c|c|c|c|c|}
\hline Customers' required quality & 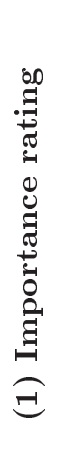 & 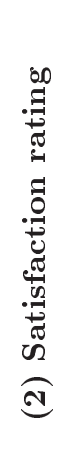 & 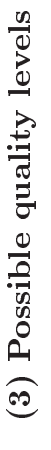 & 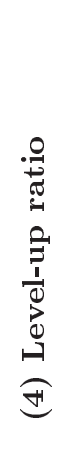 & 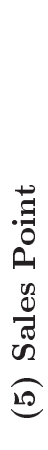 & 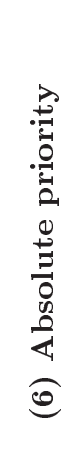 & 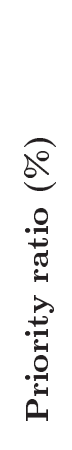 & 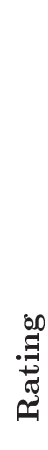 \\
\hline Easy to supply material & 3.9 & 3.4 & 5 & 1.5 & - & 5.8 & 5.4 & 6 \\
\hline Less extra cost & 3.7 & 2.7 & 3 & 1.1 & - & 4.0 & 3.7 & 11 \\
\hline Easy delivery & 4.5 & 3.2 & 5 & 1.6 & () & 10.7 & 9.9 & 4 \\
\hline Short construction period & 4.7 & 1.9 & 5 & 2.7 & - & 12.7 & 11.8 & 3 \\
\hline Easy to disassemble & 4.7 & 1.4 & 5 & 3.5 & ( & 24.7 & 23.0 & 1 \\
\hline Compatible to other modules & 4.5 & 1.6 & 3 & 1.9 & $\circ$ & 10.2 & 9.5 & 5 \\
\hline Less construction cost & 4.3 & 2.5 & 5 & 2.0 & (॰) & 12.9 & 12.0 & 2 \\
\hline Less energy consumption & 3.9 & 2.9 & 2 & 1.0 & - & 3.9 & 3.6 & 13 \\
\hline Less hot in summer & 4.5 & 2.6 & 2 & 1.0 & - & 4.5 & 4.2 & 9 \\
\hline Less cold in winter & 4.5 & 2.5 & 3 & 1.2 & - & 5.4 & 5.0 & 7 \\
\hline Good daylight performance & 4.0 & 3.0 & 2 & 1.0 & - & 4.0 & 3.7 & 11 \\
\hline Good sound insulation & 4.6 & 2.8 & 2 & 1.0 & - & 4.6 & 4.3 & 8 \\
\hline Good ventilation & 4.2 & 2.9 & 2 & 1.0 & - & 4.2 & 3.9 & 10 \\
\hline \multicolumn{9}{|c|}{ (1) Importance rating: Values obtained from customer survey $(1 \sim 5)$; } \\
\hline \multicolumn{9}{|c|}{ (2) Satisfaction rating: Values obtained from customer survey $(1 \sim 5)$; } \\
\hline \multicolumn{9}{|c|}{ (3) Possible quality levels from a viewpoint of developers $(1 \sim 5)$; } \\
\hline \multicolumn{9}{|l|}{ (4) Level-up ratio: $(3) /(2)$; } \\
\hline \multicolumn{9}{|c|}{ (5) Sales point from a viewpoint of developers (๑: $1.5, \circ$ : 1.2 , no symbol: 1.0 ); } \\
\hline
\end{tabular}

derived. Among 11 quality characteristics in the table, the top 6 are selected as the parameters Critical To Quality (CTQs) and used to set up development targets.

Next, the development targets can be set by analyzing the current levels of the potential CTQs in Table 3 and performing a benchmarking analysis. The benchmark target of this study is set by referring to a military modular system developed by a UKbased company, Corus Living Solutions (CLS) [7]. The target levels of the potential CTQs are summarized in Table 4. Among them, "no. of module types", "no. of types of structural members", and "no. of connections during on-site construction" are difficult to quantify consistently, and "module length" does not contribute significantly to module improvement. Therefore, "factory manufacturing ratio" and "weight of frames per unit area" are chosen as the final CTQs.

\section{Derivation of design concepts}

Based on the selected CTQs in the previous section, key functions are derived to design a new modular military housing unit. A correlation analysis between the quality characteristics and key functions is performed, as shown in Table 5. The results of the analysis indicate that highly prioritized functions include "connecting exterior panels", "connecting plumbing pipes", "waterproofing during delivery", "connecting corridor panels", and "loading on trailer".

Table 6 shows possible solutions for each key function. For instance, three solutions are available for the required functions of "connecting exterior panels" and "connecting corridor panels." Possible design concepts can be developed by combining the available solutions for each key function. An example of a design concept obtained by a combination of solutions 
Table 3. Correlation analysis between customers' required qualities and quality characteristics.

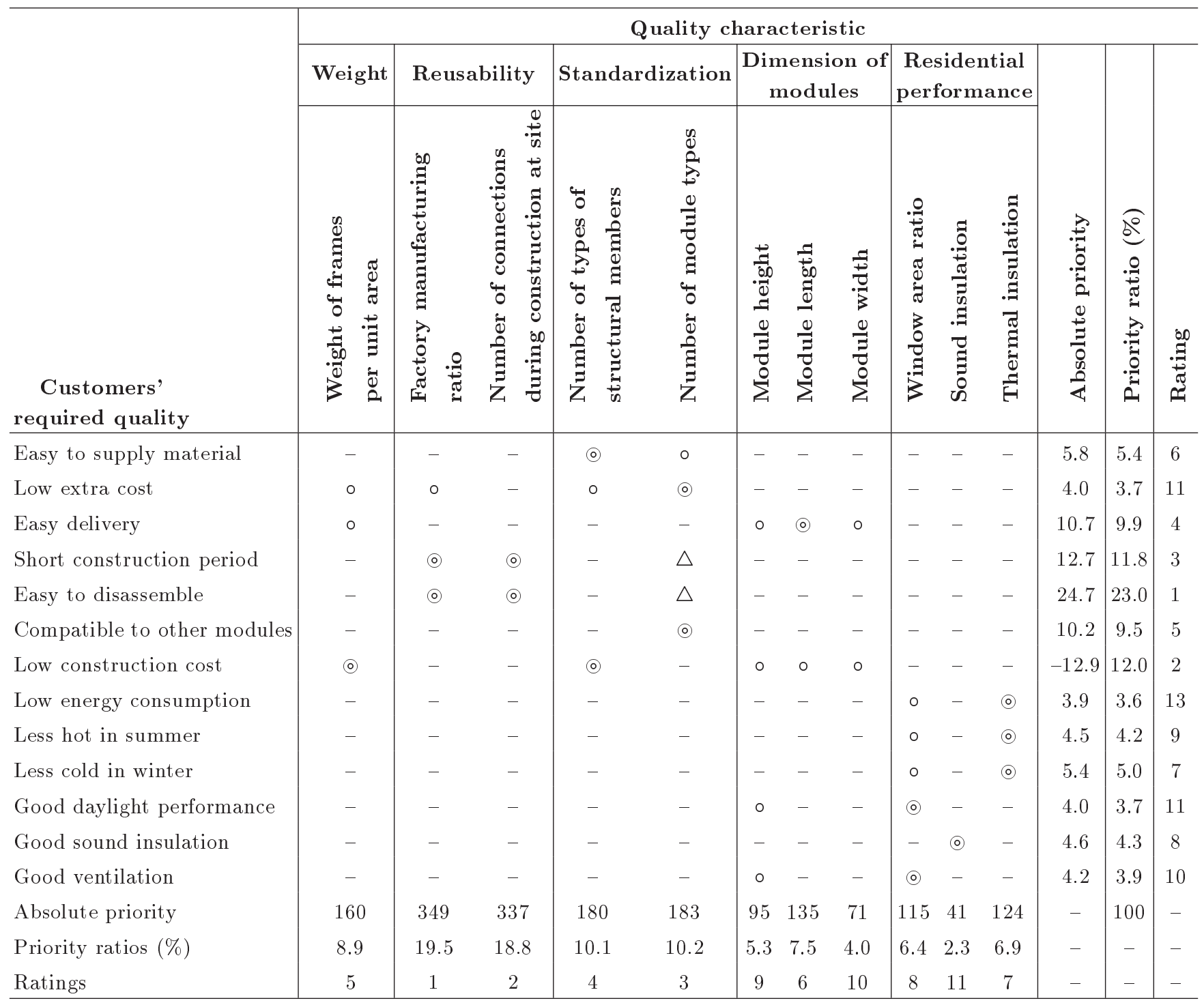

Table 4. Target levels of the potential CTQs.

\begin{tabular}{|c|c|c|c|c|c|c|c|}
\hline Potential CTQs & & $\begin{array}{c}\text { Factory } \\
\text { manufacturing } \\
\text { ratio }\end{array}$ & $\begin{array}{c}\text { No. of } \\
\text { connections } \\
\text { during } \\
\text { construction } \\
\text { on site }\end{array}$ & $\begin{array}{c}\text { No. of } \\
\text { module types }\end{array}$ & $\begin{array}{c}\text { No. of } \\
\text { types of } \\
\text { structural } \\
\text { members }\end{array}$ & $\begin{array}{l}\text { Weight } \\
\text { of frames } \\
\text { per unit } \\
\text { area }\end{array}$ & $\begin{array}{l}\text { Module } \\
\text { length }\end{array}$ \\
\hline CTQ priority ratio (\%) & & 19.5 & 18.8 & 10.2 & 10.1 & 8.95 & 7.54 \\
\hline Default level & & $42 \%$ & 0.15 per $\mathrm{m}^{2}$ & 5 & 6 & $0.76 \mathrm{kN} / \mathrm{m}^{2}$ & $6 \mathrm{~m}$ \\
\hline Target level & & $70 \%$ & 0.1 per $\mathrm{m}^{2}$ & 4 & 3 & $0.59 \mathrm{kN} / \mathrm{m}^{2}$ & $6 \mathrm{~m}$ \\
\hline & Leve & & & & & & \\
\hline Competitive & 5 & & & & & & \\
\hline benchmark & 4 & & & & & & \\
\hline$\star$ Benchmark class & 3 & & & & & & \\
\hline - Default level & 2 & & & & & & \\
\hline - Target level & 1 & & & & & & \\
\hline
\end{tabular}


Table 5. Correlation between the quality characteristics and key functions.

\begin{tabular}{|c|c|c|c|c|c|c|c|c|c|c|c|c|c|c|c|c|c|}
\hline \multirow[b]{3}{*}{ Quality characteristics } & \multicolumn{17}{|c|}{ Key functions } \\
\hline & \multirow{2}{*}{\multicolumn{2}{|c|}{ 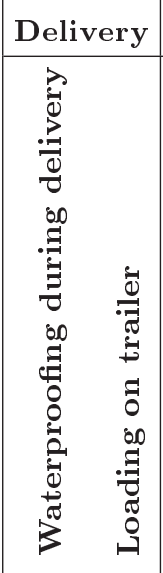 }} & \multirow[b]{2}{*}{ 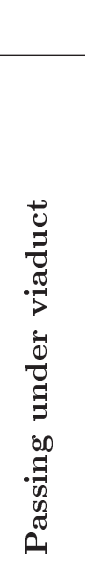 } & \multicolumn{6}{|c|}{ Assembly of modules } & \multirow[b]{2}{*}{ 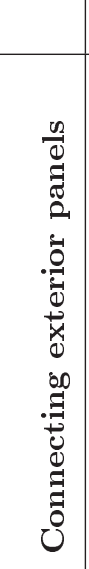 } & \multicolumn{7}{|c|}{ Performance of modules } \\
\hline & & & & 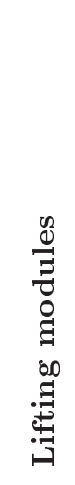 & 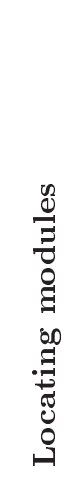 & 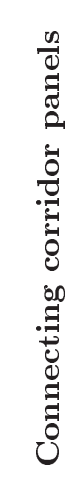 & 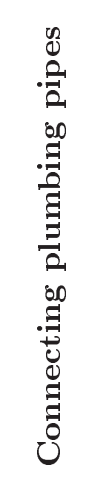 & 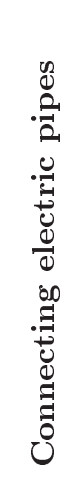 & 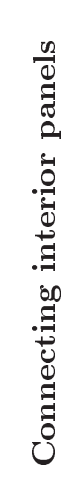 & & 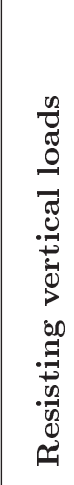 & 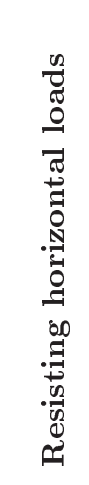 & 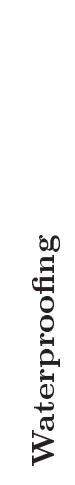 & 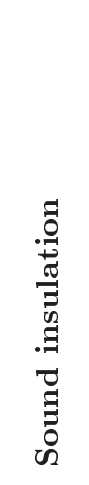 & 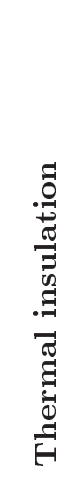 & 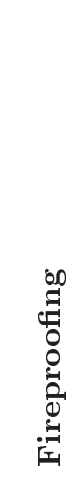 & 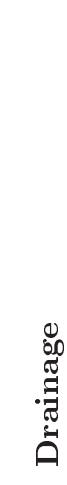 \\
\hline Factory manufacturing ratio & (๑) & $\circ$ & - & - & - & $\circ$ & (๑) & $\circ$ & $\circ$ & $\odot$ & - & - & $\circ$ & - & - & - & - \\
\hline Number of connections at site & $\circ$ & - & - & - & - & (๑) & ๑ & $\circ$ & - & $\odot$ & - & $\circ$ & - & - & - & $\circ$ & - \\
\hline Number of kinds of modules & - & - & - & - & $\circ$ & - & - & - & - & - & $\circ$ & - & - & - & - & - & - \\
\hline $\begin{array}{l}\text { Number of kinds of } \\
\text { structural members }\end{array}$ & - & - & - & ( ) & - & - & - & - & - & - & - & - & - & - & - & - & - \\
\hline Weight of frames per unit area & - & ๑) & - & ○ & $\circ$ & - & - & - & - & - & $\circ$ & $\circ$ & - & - & - & - & - \\
\hline Module length & - & - & - & - & - & - & - & - & - & - & - & - & - & $\circ$ & $\circ$ & - & - \\
\hline Thermal insulation & - & - & - & - & - & - & - & - & - & - & - & - & - & - & - & - & - \\
\hline Window area ratio & - & - & - & - & - & - & - & - & - & $\circ$ & - & - & - & - & (๑) & - & - \\
\hline Module height & - & - & (อ) & - & - & - & - & - & - & - & - & - & - & - & - & - & $\circ$ \\
\hline Module width & - & $\odot$ & - & - & - & - & - & - & - & - & - & - & - & - & - & - & - \\
\hline Sound insulation & - & - & - & - & - & - & - & - & - & - & - & - & - & (อ) & - & - & - \\
\hline Priority ratio (\%) & 10.6 & 8.0 & 2.2 & 7.8 & 2.6 & 10.4 & 15.7 & 5.2 & 2.7 & 16.6 & 2.6 & 3.8 & 2.7 & 2.0 & 3.7 & 2.6 & 0.7 \\
\hline Rating & 3 & 5 & 15 & 6 & 12 & 4 & 2 & 7 & 10 & 1 & 12 & 8 & 10 & 16 & 9 & 14 & 17 \\
\hline
\end{tabular}

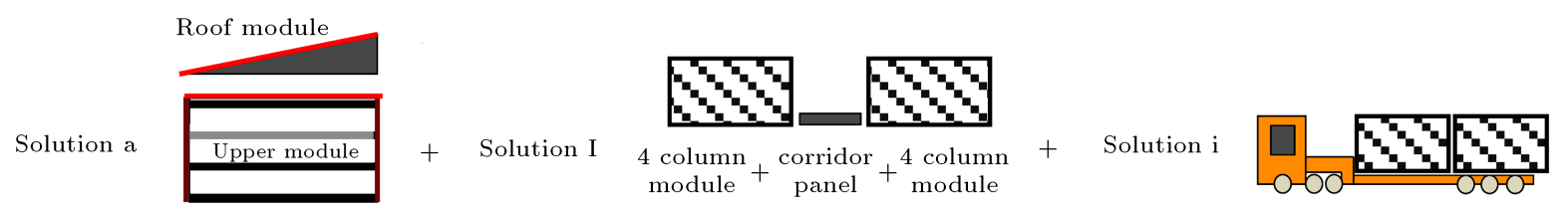

Figure 4. An example of a design concept obtained by a combination of solutions.

is shown in Figure 4. A total of five design concepts are derived by following this procedure. A Pugh matrix is created to select the optimal design among the candidates listed in Table 7 . In this table, a relative evaluation of each candidate is carried out by comparing it with the design of the existing modular system for each of the key criteria. The results of the table indicate that the design concept (2) is the optimal one. Thus, it is selected as the final design of the new military modular housing unit.

\section{Detailed design and design verification}

\subsection{Detailed design}

In this section, a detailed design is created based on the concept derived from the previous section. Figure 5 shows the plan of a representative example of Reinforced Concrete (RC) military housing units in Korea. The developed modular design concept is applied to the design of this representative example.

The military housing unit for a single person is 
Table 6. Possible solutions for each key function.

Key functions
$\begin{aligned} & \text { Locating windows at the } 1 \\ & \text { Locating windows at the } \\ & \text { cennecting } \\ & \text { exterior panels }\end{aligned}$
side of module front

\section{Sol. a:}

Making a separate roof module and installing waterproofing sheet on top of the module.

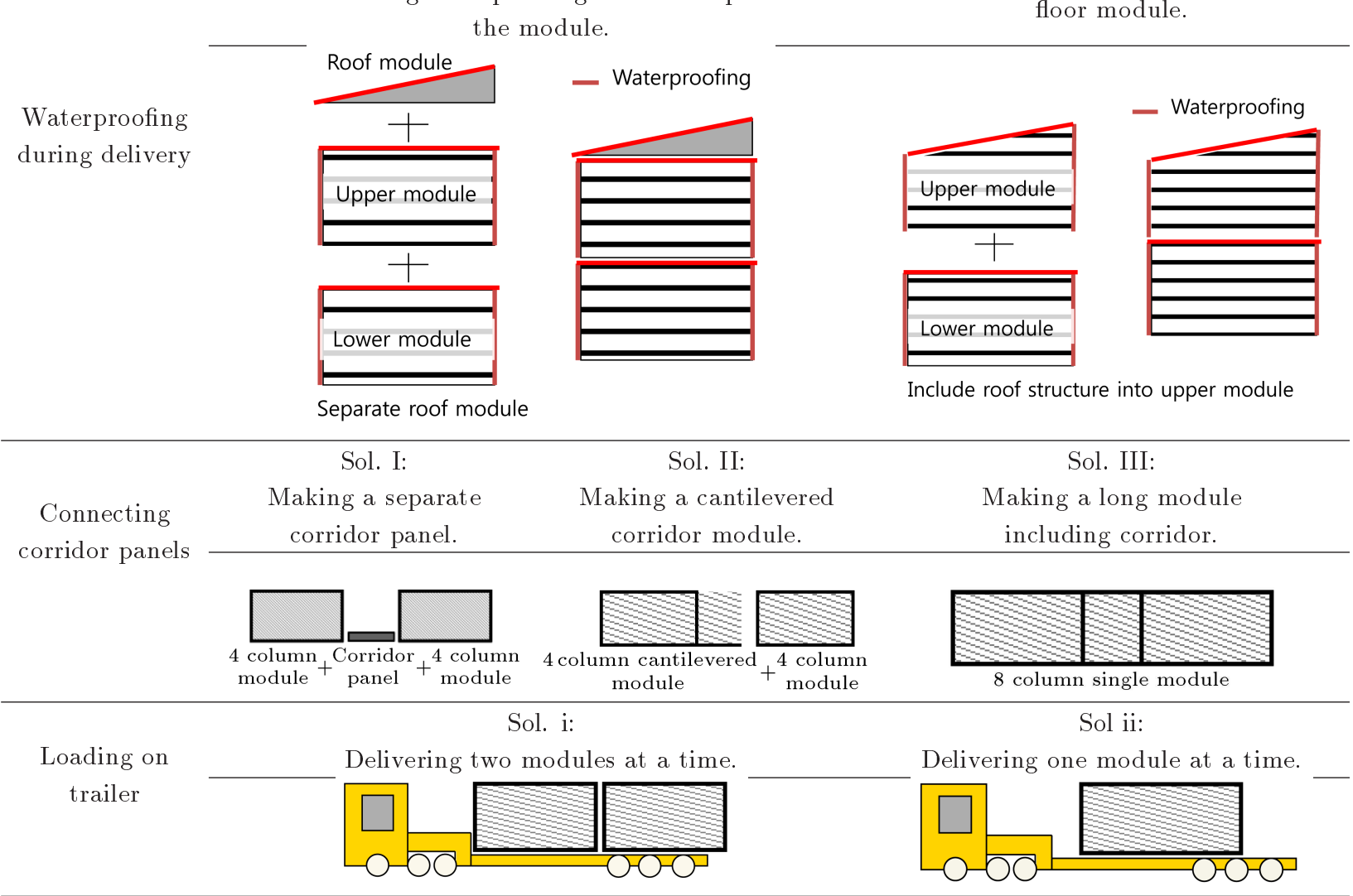

designed to have the same size similar to the factorybuilt module with a width of $3.3 \mathrm{~m}$. Windows and pipe shafts are included in the unit to maximize the factory manufacturing ratio. Table 8 presents the results of a detailed unit room design. The cross-sectional details of the representative example are given in Table 9 . The sloped roof frame is integrated into top story units to minimize the weight of frames per unit area while increasing the factory manufacturing ratio. The detailed frame design of the representative example is 
Table 7. Derivation of the final design concept using a Pugh matrix.

\begin{tabular}{|c|c|c|c|c|c|c|c|}
\hline \multicolumn{2}{|c|}{ Design concept } & \multirow{2}{*}{ 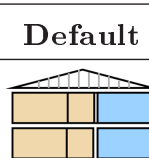 } & \multirow{2}{*}{$\begin{array}{l}\text { Concept } 1 \\
\square=\square \\
\square=\square\end{array}$} & \multirow{2}{*}{$\begin{array}{l}\text { Concept } 2 \\
\square \\
+\square\end{array}$} & \multirow{2}{*}{ 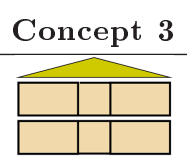 } & \multirow{2}{*}{ 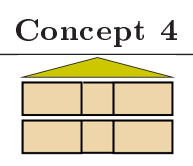 } & \multirow{2}{*}{$\begin{array}{l}\text { Concept 5 } \\
\begin{array}{|l|l|l|} & & \\
& & \\
\end{array}\end{array}$} \\
\hline Key criterion & Weight & & & & & & \\
\hline Frame cost & 5 & $\mathrm{~S}$ & $\mathrm{~S}$ & + & $\mathrm{S}$ & $\mathrm{S}$ & + \\
\hline Easy delivery & 3 & S & + & + & + & - & - \\
\hline Reusability & 5 & S & S & + & - & + & + \\
\hline $\begin{array}{l}\text { Site construction } \\
\text { time }\end{array}$ & 3 & S & - & + & - & + & + \\
\hline $\begin{array}{l}\text { Military } \\
\text { design guide }\end{array}$ & 4 & S & S & $\mathrm{S}$ & + & + & - \\
\hline $\begin{array}{l}\text { Manufacturing } \\
\text { cost }\end{array}$ & 4 & S & + & - & S & - & - \\
\hline Compatibility & 4 & S & + & - & S & + & S \\
\hline Creativity & 2 & S & S & + & + & S & S \\
\hline Sum of positives & & 0 & 3 & 5 & 3 & 4 & 3 \\
\hline Sum of negatives & & 0 & 1 & 2 & 2 & 2 & 3 \\
\hline Sum of the sames & & 8 & 4 & 1 & 3 & 2 & 2 \\
\hline Weighted sum of & sitives & 0 & 12 & 18 & 10 & 16 & 12 \\
\hline Weighted sum of & ratives & 0 & -3 & -8 & -7 & -8 & -12 \\
\hline
\end{tabular}

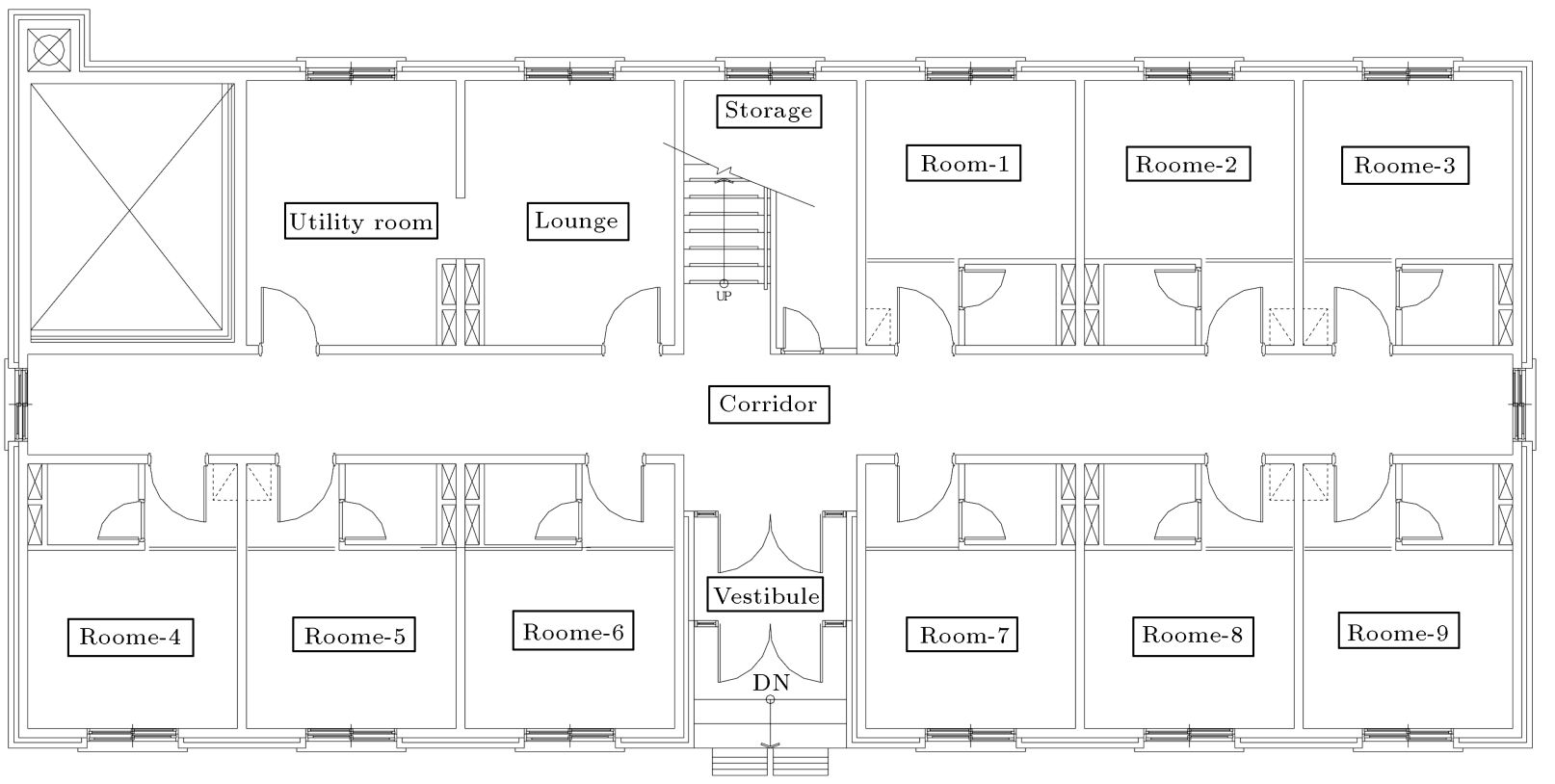

Figure 5. Plan of a representative example of RC military housing units.

illustrated in Table 10. As shown in the table, four types of unit frames are assembled to form a single frame unit, and the double-sided corridor is attached on the side of the module in the form of a cantilever. In addition, duplicated column sections are eliminated to optimize the design of frame modules. Figure 6 shows the plan and bird's-eye view of the final design of the representative military housing units, which has 20 modular unit rooms and is constructed by combining totally 29 modular units. 
Table 8. Detailed unit room design of the representative example.

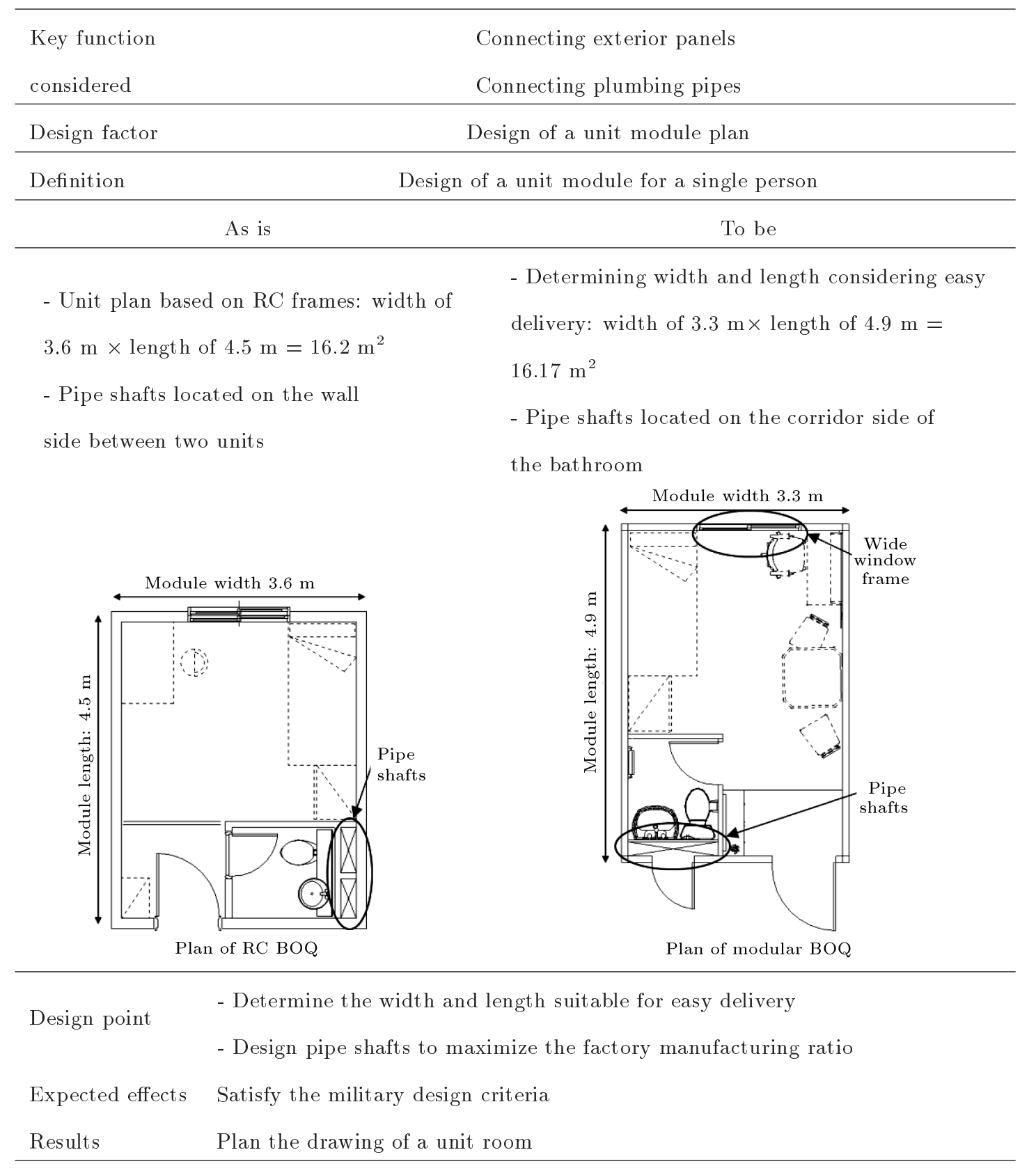

\subsection{Design verification}

In this section, a design verification of the final product of the military housing units developed in the previous section is performed. The adequacy of the developed system is investigated by evaluating the achievement of the target levels of the two final CTQs listed in Table 4. The results of the verification are summarized in Table 11.

The achievement level of the first CTQ, which is the factory manufacturing ratio, is assessed based on the ratio of manufacturing cost to the total construction cost excluding foundation and transportation. The results of the table indicate that the factory manufac- turing ratio of the final product is $75.2 \%$. Considering that the corresponding value of the existing modular military housing units is $42.9 \%$, it is almost $80 \%$ improvement and exceeds the target value, which is $70 \%$. This is possible mainly because most of the piping lines and internal finishing are manufactured in the factory, thus resulting in better product quality. The weight of frames per unit area of the developed modular system, which is the second CTQ, is $0.60 \mathrm{kN} / \mathrm{m}^{2}$, which is also greater than the target value, $0.59 \mathrm{kN} / \mathrm{m}^{2}$. This is only $62 \%$ of the corresponding value of the existing modular system. Consequently, the results of the comparison show that the use of the new modular 
Table 9. Detailed cross-sectional design of the representative example.

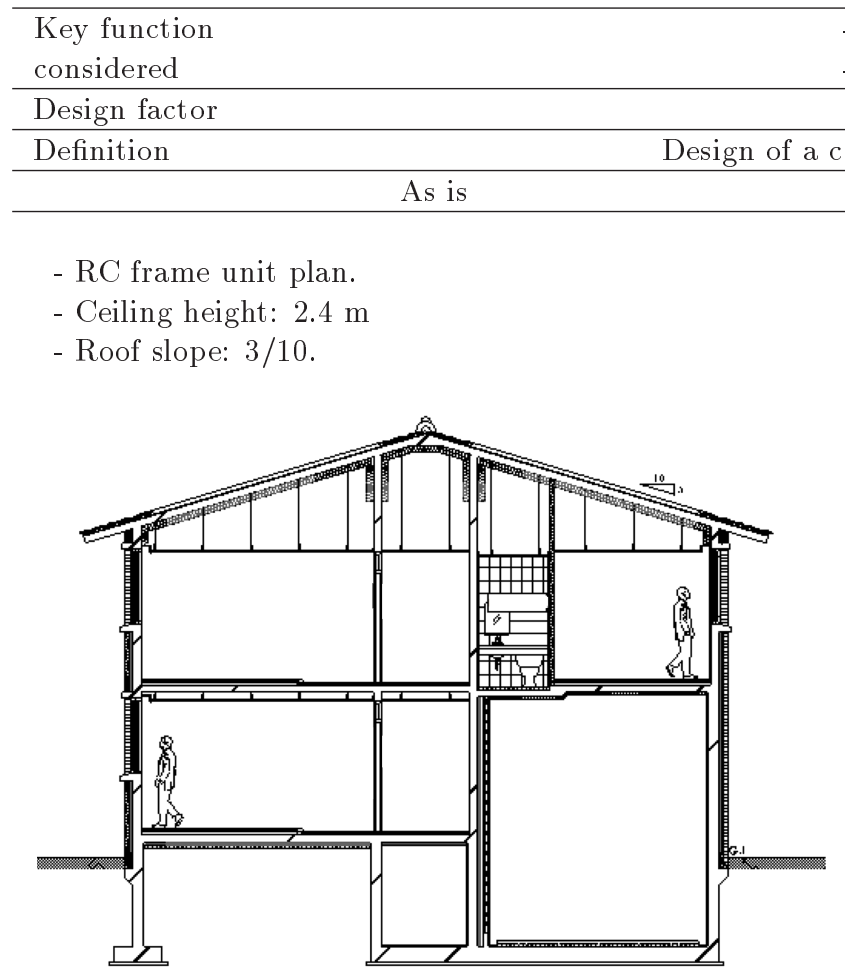

Section of RC BOQ
- Connecting exterior panels.

- Connecting plumbing pipes.

Design of a cross-section.

ross-section of the representative example.

- Sloped roof with 1/10 slope.

- Ensure at least the ceiling height of $2.4 \mathrm{~m}$.

Average ceiling height of top story is higher than $2.4 \mathrm{~m}$.

- Horizontal pipes are located at the ceiling of corridor.

- Vertical pipes are connected at the underground pit.

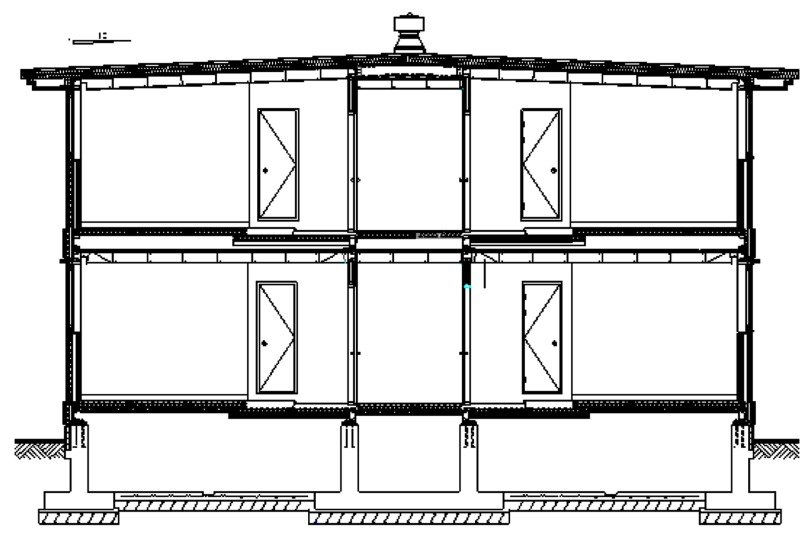

Section of RC BOQ

Design point Minimizing module height while satisfying the military design criteria.

Expected effects $\quad$ Enhanced cost-effectiveness due to reduced story height.

Results Planning the drawing of a unit room.

Table 10. Detailed frame design of the representative example.

\begin{tabular}{l}
$\begin{array}{l}\text { Key functions } \\
\text { considered }\end{array}$ \\
\hline Design factor
\end{tabular}



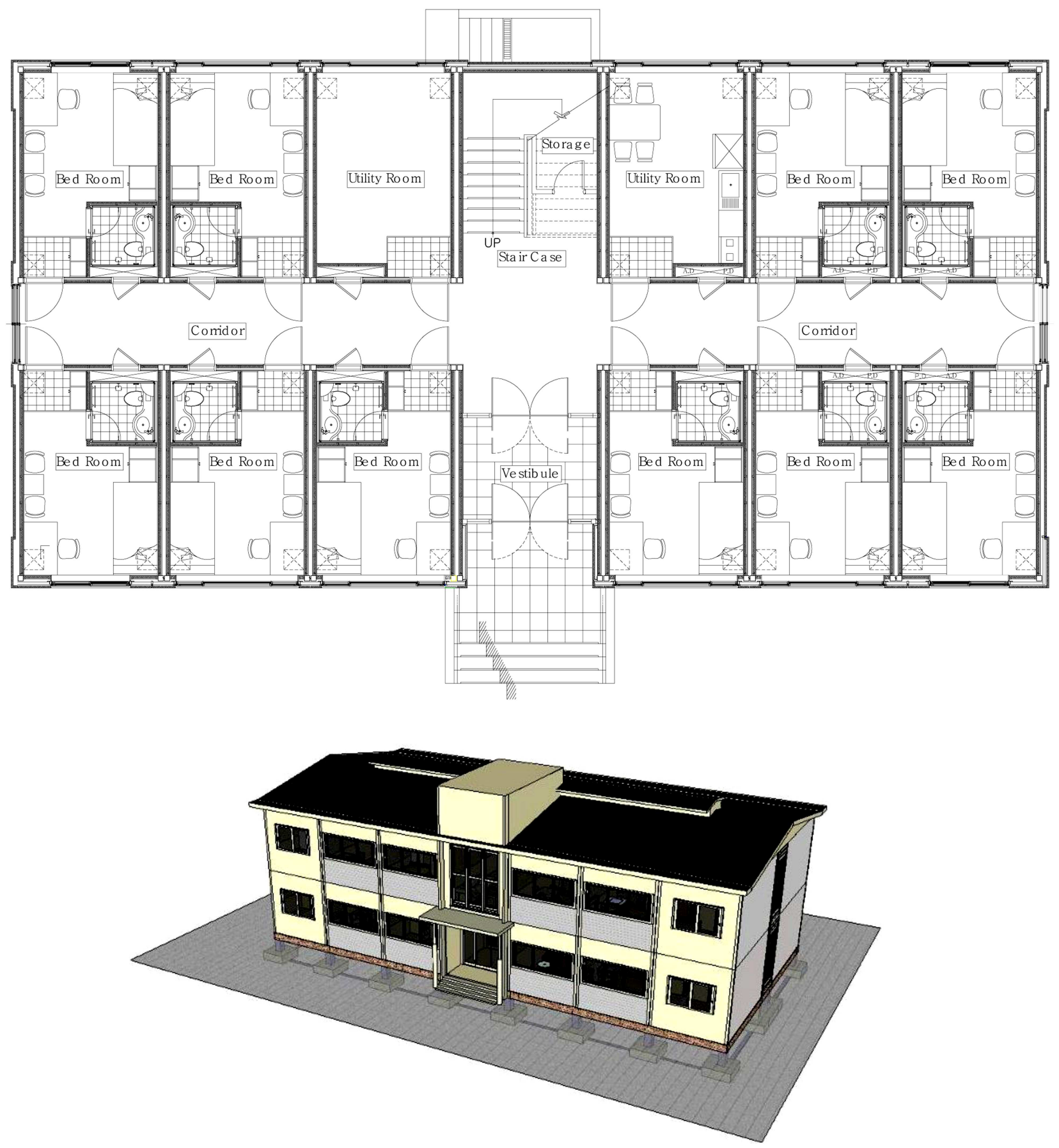

Figure 6. Plan and bird's-eye view of the newly designed military housing units.

Table 11. Verification of the designed final product.

\begin{tabular}{llcc}
\hline \multicolumn{1}{c}{ CTQs } & \multicolumn{1}{c}{ Verification method } & Target value & Design result \\
\hline $\begin{array}{l}\text { Factory } \\
\text { manufacturing } \\
\text { ratio }\end{array}$ & $\begin{array}{l}\text { Ratio of manufacturing cost to } \\
\text { the total construction cost } \\
\text { excluding foundation and } \\
\text { transportation }\end{array}$ & $70 \%$ & $75.2 \%$ \\
\hline $\begin{array}{l}\text { Weight of frames } \\
\text { per unit area }\end{array}$ & $\begin{array}{l}\text { Weight of steel frames } \\
\text { divided by floor area }\end{array}$ & $0.59 \mathrm{kN} / \mathrm{m}^{2}$ & $0.60 \mathrm{kN} / \mathrm{m}^{2}$ \\
\hline
\end{tabular}


units not only reduces construction cost significantly, but also greatly improves the quality of construction.

\section{Concluding remarks}

This study proposed a systematic approach to the design of modular military housing units based on Six-Sigma concept. The application of the Six-Sigma to modular military housing units allows customers' needs to be reflected on the CTQ, which summarizes the main design requirements, and the design concept of the modular units can be developed based on the derived CTQs. To evaluate the effectiveness of the proposed approach, a representative example of military housing units was chosen and designed by utilizing the new modular units developed through this procedure. The weight of frames per unit area and the factory manufacturing ratio of the new design were analyzed. If compared to the existing modular system, the former is improved by $80 \%$, and the latter is reduced by $62 \%$. This indicates that the use of the new modular units not only reduces construction cost significantly, but also greatly improves the quality of construction.

\section{Acknowledgement}

This work was supported by a National Research Foundation of Korea (NRF) grant funded by the Korean government (Ministry of Science, ICT \& Future Planning) (No. 2017R1A2B4004729).

\section{References}

1. Lawson, R.M. and Ogden, R.G. " Hybrid' light steel panel and modular systems", Thin-Walled Structures, 46(7-9), pp. 720-730 (2008).

2. Hong, S.-G., Cho, B.-H., Chung, K.S., and Moon, J.H. "Behavior of framed modular building system with double skin steel panels", Journal of Construction Steel Research, 67(6), pp. 936-946 (2011).

3. Park, J.S. and Park, T.K. "A study on modular construction method in military facilities", Proceedings of AIK Spring Conference, 01, pp. 565-570 (2006).

4. Ha, T.-H., Cho, B.-H., Kim, H., and Kim, D.-J. "Development of an efficient steel beam section for modular construction based on six-sigma", Advances in Materials Science and Engineering, Article ID 9687078, 13 pages (2016).

5. Pheng, L.S. and Hui, M.S. "Implementing and applying six-sigma in construction", Journal of Construction Engineering and Management, ASCE, 130(4), pp. 482489 (2004).

6. Hassan, A., Siadat, A., Dantan, J.-Y., and Martin, P. "Conceptual process lanning-an improvement approach using QFD, FMEA and ABC methods", Robotics and Computer-Integrated Manufacturing, 26(4), pp. 392-401 (2010).

7. Lawson, M., Ogden, R., and Goodier, C., Design in Modular Construction, CRC Press (2014).

\section{Biographies}

Bong-Ho Cho is a Professor at the Department of Architectural Engineering at Ajou Hee University, Suwon, Korea. He received his BS, MS, and $\mathrm{PhD}$ from the Department of Architecture, Seoul National University, Seoul, South Korea in 1996, 1998, and 2002, respectively. His current research interests include modular (prefab) construction and seismic structural engineering.

Dae-Jin Kim is an Associate Professor at the Department of Architectural Engineering at Kyung Hee University, Yongin, Korea. He received his BS and MS from Seoul National University in Korea in 1998 and 2000, respectively, and his $\mathrm{PhD}$ from the University of Illinois at Urbana-Champaign in 2009. His research interests include the composite structure design and analysis, partition of unity-based finite element analysis technique, and strut-and-tie modeling of reinforced concrete members.

Taehyu Ha is a Principal Researcher at the Steel Solution Center, Posco, Incheon, South Korea. He received his BS, MS, and $\mathrm{PhD}$ from the Department of Architecture, Seoul National University, Seoul, South Korea in 2000, 2002, and 2008, respectively. His research interests include constructional steel materials and seismic design of tall building structures. 